\title{
A Universal Approach to Target Various HBB Gene Mutations in Hematopoietic Stem/Progenitor Cells for Beta-Thalassemia Gene Therapy by CRISPR/Cas9 and the rAAV6 Vector
}

Research

Keywords:

Posted Date: December 23rd, 2020

DOl: https://doi.org/10.21203/rs.3.rs-56828/v2

License: (1) This work is licensed under a Creative Commons Attribution 4.0 International License. Read Full License 


\section{Abstract}

The authors have requested that this preprint be withdrawn due to erroneous posting.

\section{Full Text}

The authors have withdrawn this preprint from Research Square. 